\title{
Protective effects of Launaea procumbens on rat testis damage by $\mathrm{CCl}_{4}$
}

Rahmat Ali Khan

\begin{abstract}
Background: Traditionally various human diseases of kidneys, hormonal imbalance and sexual diseases are treated with Launaea procumbens $(\mathrm{L})$. In the present study protective effects of methanolic extract of Launaea procumbens (LPME) was evaluated against $\mathrm{CCl}_{4}$-induced oxidative damages in rat testis.

Methods: To examine the protective effects of Launaea procumbens on testis against oxidative stress of carbon tetrachloride in male rat, 30 male albino rats were equally divided into 5 groups (6 rats). First group was given standard diet and drinking water. Second group received $\mathrm{CCl}_{4} 3 \mathrm{ml} / \mathrm{kg}$ intraperitoneally (30\% in olive oil). Third and forth were given orally 100; 200 mg/kg b.w., in 99.8\% dimethyl sulphooxide (DMSO), Launaea procumbens methanolic extracts (LPME) after $48 \mathrm{~h}$ of $\mathrm{CCl}_{4}$ treatment twice a week and sixth group received only LPME in DMSO at a dose of $200 \mathrm{mg} / \mathrm{kg}$ b.w., for four weeks. Protective effects of Launaea procumbens were observed on sperm concentration, motility and morphology, serum reproductive hormonal level, activity of antioxidant enzymes, lipid peroxidation (TBARS) and DNA damages.

Results: Results of the present study revealed that treatment of $\mathrm{CCl}_{4}$ significantly $(p<0.01)$ reduced sperm concentration and motility comparatively to controls. Level of testosterone, luteinizing hormone and follicle stimulating hormone, were depleted markedly $(p<0.01)$ with treatment of $\mathrm{CCl}_{4}$. In addition, $\mathrm{CCl}_{4}$ induction in rats reduced activities of antioxidant enzymes while increased lipid peroxidation and DNA damages. Co-administration of LPME significantly $(p<0.01)$ improved these alterations in improving of hormonal level, activities of antioxidant enzymes and lipid peroxidation near to control rats.
\end{abstract}

Conclusion: From the results it is suggested that Launaea procumbens methanolic extract has the ability to protect testis against oxidative damages, possibly through antioxidant effects of its bioactive compounds.

Keywords: Launaea procumbens, GSH, $\mathrm{CCl}_{4}$, Lipidperoxidation, DNA damages

\section{Background}

Male sexual dysfunction composed of several problems associated with sperm concentration, motility and hormonal imbalance e.g., low testosterone level, which are caused by alcoholism, drug abuse, aging and cigarette smoking, anti depressant drugs and exposure of toxic chemicals [1-3]. Carbon tetrachloride is an industrial solvent cause kidney, lungs and testicular damages in experimental animals [4] triggers oxidative damages through free radicals produced from $\mathrm{CCl}_{4}$ metabolism [5]. Free radicals of $\mathrm{CCl}_{4}$ bind with polyunsaturated fatty acid (PUFA) of sperm membrane to produce alkoxy and

Correspondence: rahmatgul_81@yahoo.com

Department of Biotechnology, Faculty of Biological Sciences, University of

Science and Technology Bannu, Bannu, KPK, Pakistan peroxy radicals that, in turn, generate lipid peroxides, that are highly reactive, change sperm concentration, alters hormonal levels, reduces enzyme activity and finally induce injury or necrosis [6,7]. Free radicals causes reduction in GSH contents and alteration of reproductive hormones, oxidative DNA damages, genetic mutation, DNA strand breakage and chromosomal alterations $[8,9]$, necrosis of spermatocytes/spermatids and degeneration in seminiferous tubules [10,11]. Medicinal plants are also in high demand for application of functional food or biopharmaceuticals because of consumer preferences. Currently various medicinal plants has been investigated based on the integrative approaches on drug development from Ayurveda. Several medicinal plants
C Bïomed Central

(c) 2012 Khan; licensee BioMed Central Ltd. This is an Open Access article distributed under the terms of the Creative Commons Attribution License (http://creativecommons.org/licenses/by/2.0), which permits unrestricted use, distribution, and reproduction in any medium, provided the original work is properly cited. 
like Digera muricata are used as a potent antioxidant against chemical induced oxidative stress [7].

Launaea procumbens is traditionally used in the treatment of rheumatism [12], kidney dysfunction [13], reproductive disorder and hormonal imbalance in male $[14,15]$. Nutritional analysis showed that Launaea procumbens composed of salicylic acid, vanllic acid, synergic acid, 2-methyl-resercinol and gallic acid [16] which has antioxidant, anticancer and anti-inflammatory properties. Therefore the present study was arranged to evaluate the traditional use of methanol extract of Launaea procumbens versus carbon tetrachloride induced oxidative stress associated reproductive hormonal changes and lipids peroxidation in rats.

\section{Materials and methods}

Plant collection and extraction

Launaea procumbens at maturity were collected from Wah Cantt District Rawalpindi (Pakistan). Plants were identified and a specimen was submitted at Herbarium of Pakistan, Quaid-i-Azam University Islamabad, Pakistan. Whole plant (leaves, stem, flowers and seeds) were shade dried at room temperature for two weeks, chopped, ground mechanically of mesh size $1 \mathrm{~mm} .2 \mathrm{~kg}$ powder of Launaea procumbens was extracted twice in 5 liter of methanol with random shaking, after a week the extract was filtered through Whatmann filter paper No. 45 , filtrate was mixed and evaporated through rotary vacuum evaporator at $40^{\circ} \mathrm{C}$ to get crude methanolic crude extract (LPME). The crude extract was stored at $4^{\circ} \mathrm{C}$ for further in vivo investigations [11].

\section{Animals}

Six week old, 30 male albino rats (180-190 g) were provided by National Institute of Health Islamabad and were kept in ordinary cages at room temperature of $25 \pm 3^{\circ} \mathrm{C}$ with a $12 \mathrm{~h}$ dark/light cycle. They were allowed to standard laboratory feed and water.

\section{Ethical approval}

The study protocol was approved by Ethical Committee of Quaid-i-Azam University Islamabad.

\section{Experimental design}

To study the antioxidant attributes of Launaea procumbens, male albino rats were equally divided into 5 groups (6 rats). Group 1 (control) have free access to food materials. Group II received $\mathrm{CCl}_{4} 3 \mathrm{ml} / \mathrm{kg}$ intraperitoneally (30\% in olive oil). Group III and IV were given orally 100; $200 \mathrm{mg} / \mathrm{kg}$ b.w. (in DMSO), Launaea procumbens methanolic extracts (LPME) after $48 \mathrm{~h}$ of $\mathrm{CCl}_{4}$ induction in rats, while group $\mathrm{V}$ received only LPME in DMSO at a dose of $200 \mathrm{mg} / \mathrm{kg}$ b.w., orally. After $24 \mathrm{~h}$ of the last treatment, all the animals were weighted and collected their blood for serum hormonal level. Then the testes and epididymis from the rats were carefully dissected and weighed independently. From the epididymis, sperm were collected, mounted on a slide and their motility assessed immediately under the microscope at $\times 10 \mathrm{ob}-$ jective. The motility assessment was expressed as percentage motile forms. The slides were later stained with Carbol Fuschin and the sperm number and morphology were examined. After the process one testis of each rat was treated with liquid nitrogen for further enzymatic and DNA damage analysis while the other was processed for histology.

\section{Serum analysis of hormone}

Serum level of testosterone, luteinizing hormone (LH) and follicle stimulating hormone (FSH) was estimated using RIA gamma counter through kits (10227-Czch Republic purchased from IMMUNOTECH Company).

\section{Assessment of antioxidant enzymes}

$70 \mathrm{mg}$ of tissue was homogenized in 10 volume of $100 \mathrm{mmol} \mathrm{KH}_{2} \mathrm{PO}_{4}$ buffer containing $1 \mathrm{mmol}$ EDTA $(\mathrm{pH} 7.4)$ and centrifuged at $12,000 \times \mathrm{g}$ for $30 \mathrm{~min}$ at $4^{\circ} \mathrm{C}$. The supernatant was collected and used for enzymatic studies. Protein concentration of tissue supernatant was determined by the method of Lowry et al. [17] using crystalline BSA as standard.

\section{Catalase assay (CAT)}

CAT activities were determined by the method of Chance and Maehly [18]. The reaction solution of CAT activities contained: $2.5 \mathrm{ml}$ of $50 \mathrm{mmol}$ phosphate buffer (pH 5.0), $0.4 \mathrm{ml}$ of $5.9 \mathrm{mmol}_{2} \mathrm{O}_{2}$ and $0.1 \mathrm{ml}$ enzyme extract. Changes in absorbance of the reaction solution at $240 \mathrm{~nm}$ were determined after one minute. One unit of CAT activity was defined as an absorbance change of 0.01 as units/min.

\section{Peroxidase assay (POD)}

Chance and Maehly [18] protocol were used determination of POD activities. $3 \mathrm{ml}$ reaction solution of POD contained $0.1 \mathrm{ml}$ enzyme extract, $2.5 \mathrm{ml} 50 \mathrm{mM}$ phosphate buffer ( $\mathrm{pH} 5.0), 0.1 \mathrm{ml}$ of $20 \mathrm{mM}$ guaiacol, and $0.3 \mathrm{ml} \mathrm{H}_{2} \mathrm{O}_{2}(40 \mathrm{mM})$. Measure absorbance changes at $470 \mathrm{~nm}$ after one minute and POD activity.

\section{Superoxide dismutase assay (SOD)}

SOD activity was estimated by the method of Kakkar et al. [19]. Reaction mixture of this method contained: $0.1 \mathrm{ml}$ of phenazine methosulphate $(186 \mu \mathrm{mol}), 1.2 \mathrm{ml}$ of sodium pyrophosphate buffer (0.052 mmol; pH 7.0), $0.3 \mathrm{ml}$ of supernatant after centrifugation $(1500 \mathrm{x} \mathrm{g}$ for $10 \mathrm{~min}$ followed by $10000 \mathrm{x} \mathrm{g}$ for $15 \mathrm{~min}$ ) of homogenate was added to the reaction mixture. Enzyme reaction 
was initiated by adding $0.2 \mathrm{ml}$ of NADH $(780 \mu \mathrm{mol})$ and stopped after $1 \mathrm{~min}$ by adding $1 \mathrm{ml}$ of glacial acetic acid. Amount of chromogen formed was measured by recording color intensity at $560 \mathrm{~nm}$. Results are expressed in units/mg protein.

\section{Estimation of lipid peroxidation assay (TBARS)}

The assay for lipid peroxidation was carried out by the modified method of Iqbal et al. [20]. The reaction mixture in a total volume of $1.0 \mathrm{ml}$ contained $0.58 \mathrm{ml}$ phosphate buffer (0.1 mol; pH 7.4), $0.2 \mathrm{ml}$ homogenate sample, $0.2 \mathrm{ml}$ ascorbic acid $(100 \mathrm{mmol})$, and $0.02 \mathrm{ml}$ ferric chloride $(100 \mathrm{mmol})$. The reaction mixture was incubated at $37^{\circ} \mathrm{C}$ in a shaking water bath for $1 \mathrm{~h}$. The reaction was stopped by addition of $1.0 \mathrm{ml} 10 \%$ trichloroacetic acid. Following addition of $1.0 \mathrm{ml} 0.67 \%$ thiobarbituric acid, all the tubes were placed in boiling water bath for 20 min and then shifted to crushed icebath before centrifuging at $2500 \times \mathrm{g}$ for $10 \mathrm{~min}$. The amount of TBARS formed in each of the samples was assessed by measuring optical density of the supernatant at $535 \mathrm{~nm}$ using spectrophotometer against a reagent blank. The results were expressed as nmol TBARS/min/ mg tissue at $37^{\circ} \mathrm{C}$ using molar extinction coefficient of $1.56 \times 10^{5} \mathrm{M}^{-1} \mathrm{~cm}^{-1}$.

\section{Glutathione-S-transferase assay (GST)}

Glutathione-S-transferase activity was assayed by the method of Habig et al. [21]. The reaction mixture consisted of $1.475 \mathrm{ml}$ phosphate buffer $(0.1 \mathrm{~mol}, \mathrm{pH} 6.5)$, $0.2 \mathrm{ml}$ reduced glutathione $(1 \mathrm{mmol}), 0.025 \mathrm{ml}$ (CDNB) $(1 \mathrm{mmol})$ and $0.3 \mathrm{ml}$ of homogenate in a total volume of $2.0 \mathrm{ml}$. The changes in the absorbance were recorded at $340 \mathrm{~nm}$ and enzymes activity was calculated as nmol CDNB conjugate formed $/ \mathrm{min} / \mathrm{mg}$ protein using a molar extinction coefficient of $9.6 \times 10^{3} \mathrm{M}^{-1} \mathrm{~cm}^{-1}$.

\section{Glutathione reductase assay (GSR)}

Glutathione reductase activity was determined by method of Carlberg and Mannervik [22]. The reaction mixture consisted of $1.65 \mathrm{ml}$ phosphate buffer: (0.1 mol; $\mathrm{pH}$ 7.6), $0.1 \mathrm{ml}$ EDTA $(0.5 \mathrm{mmol}), 0.05 \mathrm{ml}$ oxidized glutathione $(1 \mathrm{mmol}), 0.1 \mathrm{ml} \mathrm{NADPH}(0.1 \mathrm{mmol})$ and $0.1 \mathrm{ml}$ of homogenate in a total volume of $2 \mathrm{ml}$. Enzyme activity was quantitated at $25^{\circ} \mathrm{C}$ by measuring disappearance of NADPH at $340 \mathrm{~nm}$ and was calculated as nmol $\mathrm{NADPH}$ oxidized/min/mg protein using molar extinction coefficient of $6.22 \times 10^{3} \mathrm{M}^{-1} \mathrm{~cm}^{-1}$.

\section{Glutathione peroxidase assay (GSH-Px)}

Glutathione peroxidase activity was assayed by the method of Mohandas et al. [23]. The reaction mixture consisted of $1.49 \mathrm{ml}$ phosphate buffer (0.1 mol; $\mathrm{pH} 7.4)$, $0.1 \mathrm{ml}$ EDTA $(1 \mathrm{mmol}), 0.1 \mathrm{ml}$ sodium azide $(1 \mathrm{mmol})$,
$0.05 \mathrm{ml}$ glutathione reductase $(1 \mathrm{IU} / \mathrm{ml}), 0.05 \mathrm{ml} \mathrm{GSH}$ ( $1 \mathrm{mmol}), 0.1 \mathrm{ml} \mathrm{NADPH}(0.2 \mathrm{mmol}), 0.01 \mathrm{ml} \mathrm{H}_{2} \mathrm{O}_{2}$ $(0.25 \mathrm{mmol})$ and $0.1 \mathrm{ml}$ of homogenate in a total volume of $2 \mathrm{ml}$. The disappearance of NADPH at $340 \mathrm{~nm}$ was recorded at $25^{\circ} \mathrm{C}$. Enzyme activity was calculated as nmol NADPH oxidized $/ \mathrm{min} / \mathrm{mg}$ protein using molar extinction coefficient of $6.22 \times 10^{3} \mathrm{M}^{-1} \mathrm{~cm}^{-1}$.

\section{Reduced glutathione assay (GSH)}

Reduced glutathione was estimated by the method of Jollow et al. [24]. $1.0 \mathrm{ml}$ sample of homogenate was precipitated with $1.0 \mathrm{ml}$ of (4\%) sulfosalicylic acid. The samples were kept at $4^{\circ} \mathrm{C}$ for $1 \mathrm{~h}$ and then centrifuged at $1200 \times \mathrm{g}$ for $20 \mathrm{~min}$ at $4^{\circ} \mathrm{C}$. The total volume of $3.0 \mathrm{ml}$ assay mixture contained $0.1 \mathrm{ml}$ filtered aliquot, $2.7 \mathrm{ml}$ phosphate buffer $(0.1 \mathrm{~mol} ; \mathrm{pH} 7.4)$ and $0.2 \mathrm{ml} \mathrm{DTNB}$ (100 mmol). The yellow color developed was read immediately at $412 \mathrm{~nm}$ on a SmartSpecTM plus Spectrophotometer. It was expressed as $\mu \mathrm{mol} \mathrm{GSH} / \mathrm{g}$ tissue.

\section{DNA fragmentation\% assay}

DNA fragmentation \% assay was conducted using the procedure of $\mathrm{Wu}$ et al. [25] with some modifications. The tissue $(50 \mathrm{mg})$ was homogenized in 10 volumes of a TE solution $\mathrm{pH} 8.0$ (5 mmol Tris- $\mathrm{HCl}, 20 \mathrm{mmol}$ EDTA) and $0.2 \%$ triton $\mathrm{X}-100.1 .0 \mathrm{ml}$ aliquot of each sample was centrifuged at $27,000 \times \mathrm{g}$ for $20 \mathrm{~min}$ to separate the intact chromatin (pellet, B) from the fragmented DNA (supernatant, T). The pellet and supernatant fractions were assayed for DNA content using a freshly prepared DPA (Diphenylamine) solution for reaction. Optical density was read at $620 \mathrm{~nm}$ with (SmartSpecTM Plus Spectrophotometer catalog \# 170-2525) spectrophotometer. The results were expressed as amount of \% fragmented DNA by the following formula;

$$
\% \text { Fragmented DNA }=\mathrm{T} \times 100 / \mathrm{T}+\mathrm{B}
$$

\section{DNA ladder assay}

DNA was isolated using proteinase $\mathrm{K}$ and RNase A with the methods of Gilbert et al. [26] to estimate DNA damages. $5 \mu \mathrm{g}$ of rat DNA was separately loaded in $1.5 \%$ agarose gel containing $1.0 \mu \mathrm{g} / \mathrm{ml}$ ethidium bromide including DNA standards ( $0.5 \mu \mathrm{g}$ per well). Electrophoresis was performed for $45 \mathrm{~min}$ at 100 Volt. After electrophoresis gel was studied under gel doc system and was photographed through digital camera.

\section{Histopathological overview of testis}

After weighting the tissue for histology, testis were placed for 3-4 hrs in formalin and transferred in cedar wood oil. After $72 \mathrm{~h}$ treatment testis were shifted in paraplast and prepared blocks for further microtomy. 
Table 1 Effect of LPME on sperm count, motility and morphology male in rat

\begin{tabular}{llll}
\hline Treatment & Count $(\mathbf{1 0} / \mathbf{m l})$ & Motility (\%) & Morphology (\%) \\
\hline Control & $32.1+/-2.78++$ & $82.3+/-5.0++$ & $11.5+/-0.95++$ \\
$3 \mathrm{ml} / \mathrm{kg} \mathrm{CCl} 4$ & $15.5+/-0.54^{* *}$ & $52.5+/-2.9^{* *}$ & $35.0+/-0.57^{* *}$ \\
$100 \mathrm{mg} / \mathrm{kg}$ & $27.0+/-0.48^{*}++$ & $70.6+/-3.3^{*}++$ & $23.1+/-0.29^{*}++$ \\
$\mathrm{LPME}+\mathrm{CCl} 4$ & & & \\
$200 \mathrm{mg} / \mathrm{kg}$ & $31.6+/-1.85++$ & $77.5+/-1.3++$ & $14.5+/-1.39++$ \\
$\mathrm{LPME}+\mathrm{CCl}$ & & & \\
$200 \mathrm{mg} / \mathrm{kg}$ & $35.7+/-2.04++$ & $84.2+/-2.0++$ & $11.3+/-1.14++$ \\
LPME alone & & & \\
\hline
\end{tabular}

*, ** indicate significance from the control group at $\mathrm{P}<0.05$ and $\mathrm{P}<0.01$ probability level, respectively.

++ indicate significance from the $\mathrm{CCl}_{4}$ group at $\mathrm{P}<0.01$ probability level, respectively.

3-4 $\mu \mathrm{m}$ thin slides were prepared with microtome; wax was removed, stained with hemotoxilin-eosin and photographed under light microscope at 40x.

\section{Statistical analysis}

Data were expressed as mean and standard error (SE) and ANOVA test was used to analyze the difference among various treatments, with least significance difference (LSD) at 0.05 and 0.01 as a level of significance. SPSS ver. 14.0 (Chicago, IL, USA) and Microsoft Excel 2007 (Roselle, IL, USA) were used for the statistical and graphical evaluations.

\section{Results}

\section{Effect of LPME on sperm parameters}

Effects of $\mathrm{CCl}_{4}$ on the sperm count and motility was significantly reduced $(p<0.01)$ while the percentage sperm abnormality was significantly $(p<0.01)$ increased after treatment with $\mathrm{CCl}_{4}$ comparatively to controls (Table 1). Administration of LPME in $\mathrm{CCl}_{4}$ treated rats significantly $(p<0.01)$ attenuated the spermatic alterations as compare to control. There was a significant decrease $(p<0.01)$ in sperm abnormal morphology in $\mathrm{CCl}_{4}$ treated rats, the percentage abnormal morphology in comparison with $\mathrm{CCl}_{4}$ treated rats. No significant $(p<0.01)$ changes was observed in rats treated with $200 \mathrm{mg} / \mathrm{kg}$ LPME alone.

\section{Effect of LPME on pituitary-gonadal axis}

The effects of LPME on testosterone, luteinizing hormone and follicle stimulating hormone are shown in Table 2. $\mathrm{CCl}_{4}$ administration in rats for 4 weeks, significantly decreased $(p<0.01)$ the hormonal level of testosterone, luteinizing hormone and follicle stimulating hormone comparatively to control group. Alterations of these hormones was significantly reversed $(p<0.01)$ by administrations of $100 \mathrm{mg} / \mathrm{kg}$ b.w., and $200 \mathrm{mg} / \mathrm{kg}$ and $200 \mathrm{mg} / \mathrm{kg}$ b.w., LPME in $\mathrm{CCl}_{4}$ treated rats however, non significant $(p>0.05)$ changes were observed in non treated LPME alone rats.

\section{Effect of LPME on antioxidant profile}

Antioxidant profile play important role in infertility. The effects of LPME against $\mathrm{CCl}_{4}$ induced antioxidant status alteration are shown in Table 3. Activities of antioxidant enzymes such as CAT, POD and SOD were significantly $(p<0.01)$ reduced by treatment of $\mathrm{CCl}_{4}$ as compared to control group. This reduction was improved significantly $(P<0.01)$ by post-administration of LPME at both $100 \mathrm{mg} / \mathrm{kg}$ and $200 \mathrm{mg} / \mathrm{kg}$ body weight near to control rat. However, non significant changes $(p>0.05)$ were found by administration of LPME alone against the control group.

\section{Effect of LPME on GSHpx, GST, GSR, GSH, TBARS}

Effect of $\mathrm{CCl}_{4}$ and the protective effects of LPME on tissue phase II metabolizing enzymes viz; GSH-Px, GST, GSR, GSH and TBARS are shown in Table $4 . \mathrm{CCl}_{4}$ treatment to rats significantly $(p<0.01)$ decreased the activities of GSH-Px, GST, GSR and GSH while significantly $(p<0.01)$ increased the contents of TBARS in tissue homogenate as compared to control group. $100 \mathrm{mg} / \mathrm{kg}$ and $200 \mathrm{mg} / \mathrm{kg}$ b.w., LPME showed significant protection and recovered $(p<0.01)$ the activity of enzymes near to control rat; increased the activities of GST, GSR and GSH while decreased the contents of TBARS in a dose

Table 2 Effect of LPME on FSH, LH, testosterone, prolactin and estradiol in rat

\begin{tabular}{|c|c|c|c|c|c|}
\hline Treatment & FSH (mg/dl) & $\mathrm{LH}(\mathrm{mg} / \mathrm{dl})$ & Testosterone (mg/dl) & Prolactin (mg/dl) & Estradiol (mg/dl) \\
\hline Control & $10.3+/-0.65++$ & $32+/-1.12++$ & $47.8+/-2.6++$ & $14+/-1.42++$ & $24.5+/-2.65++$ \\
\hline $3 \mathrm{ml} / \mathrm{kg} \mathrm{CCl} 4$ & $4.9+/-0.82^{* *}$ & $14.8+/-2.51^{* *}$ & $25.7+/-3.6^{* *}$ & $33.6+/-2.6^{* *}$ & $60.3+/-2.8^{* *}$ \\
\hline $100 \mathrm{mg} / \mathrm{kg} \mathrm{LPME}+\mathrm{CCl}_{4}$ & $9.1+/-0.54++$ & $31.9+/-3.04++$ & $42.0+/-2.09++$ & $16.0+/-2.02++$ & $30.5 .3+/-3.5++$ \\
\hline $200 \mathrm{mg} / \mathrm{kg} \mathrm{LPME}+\mathrm{CCl}_{4}$ & $11.5+/-0.57++$ & $31.4+/-2.87++$ & $44.5+/-3.50^{* *}++$ & $16.5+/-3.21^{*}++$ & $32.4+/-2.8++$ \\
\hline 200 mg/kg LPME alone & $11.5+/-0.58++$ & $33.3+/-3.12++$ & $46.5+/-4.20++$ & $13.50+/-1.51++$ & $23.6+/-1.67++$ \\
\hline
\end{tabular}

Mean \pm SE ( $n=6$ number).

*, ** indicate significance from the control group at $P<0.05$ and $P<0.01$ probability level.

++ indicate significance from the $\mathrm{CCl}_{4}$ group at $P<0.01$ probability level. 
Table 3 Effect of LPME on testis CAT, POD and SOD activity in rat

\begin{tabular}{lllll}
\hline Treatment & Protein $(\boldsymbol{\mu g} / \mathbf{m g}$ tissue) & CAT $(\mathbf{U} / \mathbf{m i n})$ & POD $(\mathbf{U} / \mathbf{m i n})$ & SOD $(\mathbf{U} / \mathbf{m g}$ protein) \\
\hline Control & $2.01+/-0.06++$ & $5.56+/-0.32++$ & $6.88+/-0.29++$ & $2.07+/-0.06++$ \\
$3 \mathrm{ml} / \mathrm{kg} \mathrm{CCl} 4$ & $0.91+/-0.03^{* *}$ & $3.06+/-0.14^{* *}$ & $3.97+/-0.09^{* *}$ & $0.97+/-0.03^{* *}$ \\
$100 \mathrm{mg} / \mathrm{kg} \mathrm{LPME}+\mathrm{CCl}_{4}$ & $1.86+/-0.00++$ & $4.73+/-0.14++$ & $4.81+/-0.09++$ & $1.35+/-0.01++$ \\
$200 \mathrm{mg} / \mathrm{kg} \mathrm{LPME}+\mathrm{CCl}_{4}$ & $2.00+/-0.07++$ & $5.69+/-0.30++$ & $6.27+/-0.29++$ & $2.00+/-0.02++$ \\
$200 \mathrm{mg} / \mathrm{kg} \mathrm{LPME}$ alone & $2.11+/-0.05++$ & $5.73+/-0.32++$ & $6.98+/-0.27++$ & $2.17+/-0.05++$ \\
\hline
\end{tabular}

Mean \pm SE ( $n=6$ number).

${ }^{*}, * *$ indicate significance from the control group at $P<0.05$ and $P<0.01$ probability level.

++ indicate significance from the $\mathrm{CCl}_{4}$ group at $P<0.01$ probability level.

dependent manner. LPME when administered alone did not show significant variations.

\section{Body weight, testis weight, relative testis weight}

Effect of $\mathrm{CCl}_{4}$ on body weight, testis weight and relative testis weight are shown in Table $5 . \mathrm{CCl}_{4}$ administration to rats significantly increased $(p<0.01)$ testis weight and relative testis weight while significantly decreased $(p<0.01)$ body weight compared to control group. Posttreatment with LPME erased the $\mathrm{CCl}_{4}$ toxicity and significantly $(p<0.01)$ improved testis weight and relative testis weight and relative tissue weight towards the control group in a dose dependent However, non significant $(p>0.05)$ variations were observed by LPME alone as compared to control group.

\section{DNA damages (DNA ladder assay; DPA assay)}

Free radicals of carbon tetrachloride cause testicular DNA fragmentation qualitatively (Figure 1) and quantitatively (Table 5) in testicular tissue. Qualitative analysis revealed that Line (5-8) of DNA printing showed that $\mathrm{CCl}_{4}$ causes damages which are absent in control (1-4). Co-administration of $100 \mathrm{mg} / \mathrm{kg}$ and $200 \mathrm{mg} / \mathrm{kg}$ b.w., LPME in $\mathrm{CCl}_{4}$ treated rats cause significant reduction $(p<0.01)$ in DNA damages. Similar observations were found in DPA method.

\section{Histology of testis in rats and LPME}

Histological appearance play important role in study of protective role of LPME in rats. Administration of $\mathrm{CCl}_{4}$ caused loss of germ cells, abnormality of germinative epithelium, interruption in meiosis; sperm with abnormal shape and concentration were visible. The ground substance within the interstitium was replaced by fibroblast and inflammatory cells as well as caused atrophy of somniferous tubules. Orally-treatment with LPME revealed a marked repairing of testicular abnormalities induced by $\mathrm{CCl}_{4}$ in dose depenent way near to control group (Table 6).

\section{Discussion}

$\mathrm{CCl}_{4}$ requires bioactivation by phase I cytochrome $\mathrm{P} 450$ system to form reactive metabolic trichloromethyl radical $\left(\mathrm{CCl}_{3}{ }^{*}\right)$ and peroxy trichloromethyl radical $\left({ }^{*} \mathrm{OOCCl}_{3}\right)$. These free radicals can bind with polyunsaturated fatty acid (PUFA) to produce alkoxy $\left(\mathrm{R}^{*}\right)$ and peroxy radicals (ROO*), that, in turn, generate lipid peroxides, that are highly reactive, change enzyme activity and finally induce injury or necrosis $[5,27]$. The injuries induced by $\mathrm{CCl}_{4}$ are resulted from free radicals through lipid per oxidation of cell membranes, reduces antioxidant enzyme and antioxidant substrates to induce oxidative stress that is an important factor in acute and chronic injuries in various tissues [28]. Launaea procumbens L. possess bioactive ingredients which play important role in reduction of oxidative stress in male albino rats [11]. Testicular oxidative stress appears to be a common feature in infertility, which suggests that, there may be benefits to develop better antioxidant therapies for relevant cases of hypo spermatogenesis [29,30]. The results of the presents study revealed that LPME had significant improvement on body weight, testicular

Table 4 Effect of LPME on testis GST, GSH-Px, GSR, GSH and TBARS in rat

\begin{tabular}{|c|c|c|c|c|c|}
\hline Treatment & $\begin{array}{l}\text { GSH-Px } \\
\text { (nM/mg protein) }\end{array}$ & $\begin{array}{l}\text { GSR } \\
\text { (nM/min/mg protein) }\end{array}$ & $\begin{array}{l}\text { GST } \\
\text { (nM/min/mg protein) }\end{array}$ & $\begin{array}{l}\text { GSH } \\
\text { ( } \mu \mathrm{M} / \mathrm{g} \text { tissue) }\end{array}$ & $\begin{array}{l}\text { TBARS } \\
\text { (nM/min/mgprotein) }\end{array}$ \\
\hline Control & $138.83+/-1.0++$ & $201.5+/-1.93++$ & $84.67+/-1.6++$ & $0.89+/-0.05++$ & $15.3+/-0.83++$ \\
\hline $3 \mathrm{ml} / \mathrm{kg} \mathrm{CCl}{ }_{4}$ & $70.50+/-0.76^{* *}$ & $115.17+/-2.2^{* *}$ & $55.17+/-1.6^{* *}$ & $0.60+/-0.09^{* *}$ & $34.1+/-0.44^{* *}$ \\
\hline $100 \mathrm{mg} / \mathrm{kg} \mathrm{LPME}+\mathrm{CCl}_{4}$ & $129.17+/-1.1++$ & $149.83+/-2.8++$ & $78.83+/-1.3++$ & $0.80+/-0.06++$ & $21.8+/-0.74++$ \\
\hline $200 \mathrm{mg} / \mathrm{kg} \mathrm{LPME}+\mathrm{CCl}_{4}$ & $138.33+/-1.4++$ & $196.8+/-3.2^{*}++$ & $85.17+/-2.8++$ & $0.81+/-0.01^{* *}++$ & $17.8+/-0.61++$ \\
\hline 200 mg/kg LPME alone & $140.6+/ - \pm 1.2++$ & $206.7+/-2.2++$ & $88.5+/-1.9++$ & $0.91+/-0.01++$ & $15.4+/-0.62++$ \\
\hline
\end{tabular}

Mean \pm SE ( $n=6$ number).

$*{ }^{* *}$ indicate significance from the control group at $P<0.05$ and $P<0.01$ probability level.

++ indicate significance from the $\mathrm{CCl}_{4}$ group at $P<0.01$ probability level. 
Table 5 Effect of LPME on testis weight, relative testis weight in rat

\begin{tabular}{llll}
\hline Treatment & Tissue weight $(\mathbf{g})$ & Relative testis weight & \%DNA Fragmentation \\
\hline Control & $6.07+/-0.32++$ & $0.067+/-0.003++$ & $5.67+/-0.55++$ \\
$3 \mathrm{ml} / \mathrm{kg} \mathrm{CCl}{ }_{4}$ & $7.91+/-0.21^{* *}$ & $0.07+/-0.002^{* *}$ & $32.67+/-1.78^{* *}$ \\
$100 \mathrm{mg} / \mathrm{kg} \mathrm{LPME}+\mathrm{CCl}_{4}$ & $6.53+/-0.67++$ & $0.06+/-0.007++$ & $7.500+/-0.7++$ \\
$200 \mathrm{mg} / \mathrm{kg} \mathrm{LPME}+\mathrm{CCl}_{4}$ & $6.08+/-0.30++$ & $0.06+/-0.003++$ & $5.33+/-0.22++$ \\
$200 \mathrm{mg} / \mathrm{kg} \mathrm{LPME}$ alone & $5.63+/-0.20++$ & $0.05+/-0.002++$ & $5.50+/-1.36++$ \\
\hline
\end{tabular}

Mean \pm SE ( $n=6$ number).

** indicate significance from the control group at $P<0.01$ probability level.

++ indicate significance from the $\mathrm{CCl}_{4}$ group at $P<0.01$ probability level.

weight and relative tissue weight. The report of Khan and Ahmed [29] revealed significant reduction in weight gain, particularly in studies initiated in male animals, during three months observation of rats receiving carbon tetra chloride in comparison to the controls. The increase in the reproductive organs weights could be due to the increase in lipid peroxidation which was observed in the current study that may be resulted from the oxidative damage induced in rat testes. The amelioration effect of LPME may be due to gallic acid and polyphenolic compounds [16]. Other studies also revealed the importance of herbal extract on testicular tissue [31-33].

$\mathrm{CCl}_{4}$ induced marked reduction in sperm count, motility (\%), with increase in dead and abnormal sperm count as compared to control group which was significantly restored with both doses of LPME. Previous reports revealed that chemical ingestion cause suppression of sexual behavior of male rats [34] and reductions in motility [35].

Antioxidant enzyme play key role in oxidative infertility. Oxidative stress may result in overproduction of oxygen free-radical precursors and/or decreased efficiency of the antioxidant system. $\mathrm{CCl}_{4}$ and oxygen free-radical generation is associated with impaired glutathione metabolism, alterations in the antioxidant status [26]. The results of our present investigation showed that $3 \mathrm{ml} / \mathrm{kg}$
$\mathrm{CCl}_{4}$ administration in rats caused significant reduction in the activity of antioxidant enzymes, GSH and increased TBARS. Reduction of antioxidant enzymes activity in testicular tissue are might be due to accumulation of free radicals leads to enhanced lipid peroxidation or inactivation of the antioxidative enzymes [36]. Glutathione contents play key role in maintaining antioxidant status. Decrease in $\mathrm{GSH}$ activity during $\mathrm{CCl}_{4}$ toxicity might be due to the decreased availability of GSH resulted during the enhanced lipid peroxidation. Improvement of testicular GSH levels in rats treated with Launaea procumbens extracts in comparison to $\mathrm{CCl}_{4}$ administration further demonstrated the antioxidative effect of the plant. Various treatments of Launaea procumbens extracts also improved the levels of antioxidant enzymes in $\mathrm{CCl}_{4}$ administered rats are due the presence of phenolic and polyphenolic constituents [13] which may have different functional properties such as scavenging of active oxygen species, inhibition of the generation of free radicals and chain breaking activity. Similar observations were also reported with black tea extract on the level of TBARS in rats after $\mathrm{CCl}_{4}$ exposure [37]. Jia et al., [8] investigated that oxidative damage can occur in DNA during the peroxidative breakdown of membrane polyunsaturated fatty acids. DNA damage affects homeostasis of various cells leading to induced

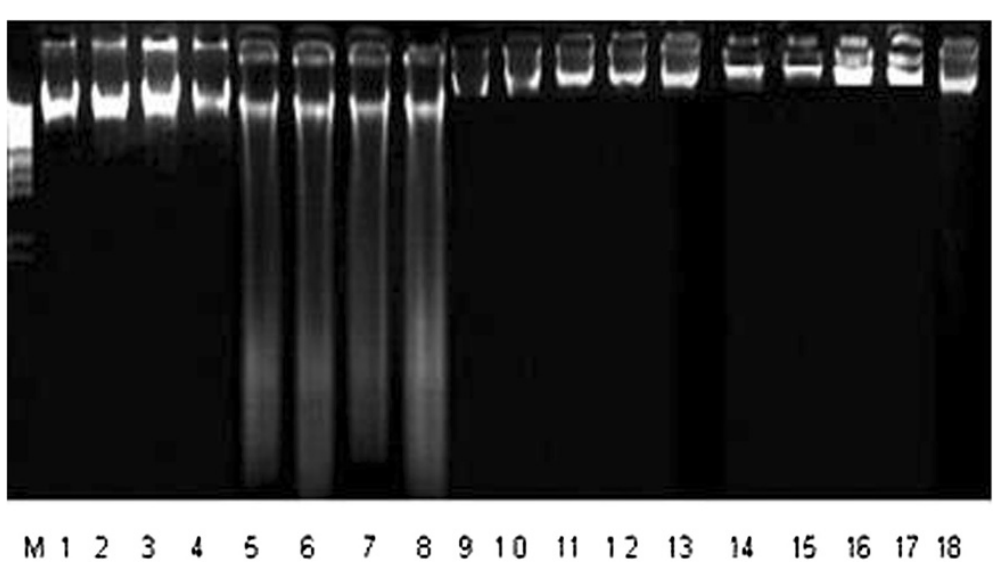

Figure 1 Agarose gel showing DNA damage by $\mathrm{CCl}_{4}$ and preventive effect of Launaea procumbens extracts in different groups. Lanes




Table 6 Effect of LPME on testicular histopathology in rat

\begin{tabular}{llllll}
\hline Treatment & $\begin{array}{l}\text { Somniferous tubules } \\
\text { degeneration }\end{array}$ & $\begin{array}{l}\text { Meiosis } \\
\text { interruption }\end{array}$ & $\begin{array}{l}\text { Sperm } \\
\text { concentration }\end{array}$ & $\begin{array}{l}\text { Germ cell } \\
\text { morphology }\end{array}$ & $\begin{array}{l}\text { Germinative } \\
\text { epithelium }\end{array}$ \\
\hline Control & - & - & - & - & - \\
$3 \mathrm{ml} / \mathrm{kg} \mathrm{CCl}$ & +++ & ++ & +++ & ++ & ++ \\
$100 \mathrm{mg} / \mathrm{kg} \mathrm{LPME}+\mathrm{CCl}_{4}$ & $-/+$ & - & $-/+$ & $-/+$ & $-/+$ \\
$200 \mathrm{mg} / \mathrm{kg} \mathrm{LPME}+\mathrm{CCl}_{4}$ & - & - & - & - & $-/+$ \\
$200 \mathrm{mg} / \mathrm{kg} \mathrm{LPME}$ alone & - & - & - & - \\
\hline
\end{tabular}

-, normal; -/+, mild; ++, medium; +++, severely damaged.

signal transductions associated with apoptosis and cell proliferation [38]. Administration of Launaea procumbens extracts to $\mathrm{CCl}_{4}$ intoxicated rats protected and markedly decreased the percentage of fragmented DNA that was also revealed in DNA ladder assay. It may contribute its protective effects by erasing the damaging action of $\mathrm{CCl}_{4}$ at DNA level. The protective potential may either involve antioxidant; signal transduction, gene expression, and effective involvement in the metabolic pathways [39].

Histopathalogical study revealed that $\mathrm{CCl}_{4}$ treatment showed marked degeneration and alterations of germ cells; however treatment of Launaea procumbens showed noticeable improvement in histopathalogical changes induced by $\mathrm{CCl}_{4}$ in testis sections. The histological changes in testes of rats administered $\mathrm{CCl}_{4}$ are in agreement with Khan and Ahmed [36] who studied the effect of Digera muricata against $\mathrm{CCl}_{4}$ induced toxicity on the rat's testes. Yousef and Salama [30] reported that oxidative stress results from the production of oxygen radicals in excess of the antioxidant capacity of the stressed tissue. Many conditions or events associated with male infertility are inducers of oxidative stress, which leads to an increase in germ cell apoptosis and subsequent hypospermatogenesis, such stress condition, endocrine signaling, and germ cell apoptosis. Moreover, reactive oxygen species and oxidative damage of bimolecular may contribute to male infertility by reducing sperm function [40]. Minimizing the hazard effects of $\mathrm{CCl}_{4}$ by LPME treatment may be due to the flavoniods in LPME, which exert many health-promoting effects, including the ability to increase intercellular antioxidant levels, decrease capillary permeability and fragility and scavenge oxidants and free radicals $[41,42]$.

\section{Conclusion}

This study provided the scientific proof that LPME is useful remedy for oxidative stress and reproductive hormonal dysfunction in male. Further work towards the isolation of bioactive constituents responsible for these activities is in progress in our lab.

\section{Competing interests}

The authors declare that they have no competing interests.

\section{Authors' contributions}

RAK made significant contribution to acquisition of data, analysis, drafting of the manuscript. The author read and approved the final manuscript.

Received: 14 May 2012 Accepted: 19 August 2012

Published: 22 August 2012

\section{References}

1. Khaki A, Fathiazad F, Nouri M, Khaki AA, Ghanbari Z, Ghanbari M, Ouladsahebmadarek E, Farzadi L: Anti-oxidative Effects of Citro_flavonoids on Spermatogenesis in Rat. Afr J Pharm Pharmaco 2011, 5(6):721-725.

2. Khaki A: Protective effect of quercetin against necrosis and apoptosis induced by experimental ischemia and reperfusion in rat liver. Afr J Pharm Pharmaco 2010, 4(1):022-026.

3. Brock GB, Mcmahon CG, Chen KK: Efficacy and safety of tadalafil for the treatment of erectile dysfunction, results of integrated analysis. J Urol 2002, 168:1332-1336.

4. Abraham P, Wilfred G, Cathrine SP: Oxidative damage to lipids and proteins of the lungs, testis and kidney of rats during $\mathrm{CCl}_{4}$ intoxication. Clinical Acta 1999, 289:177-179.

5. Bruckner JV, Ramanathan R, Lee KM, Muralidhara S: Mechanisms of circadian rhythmicity of carbon tetrachloride hepatotoxicity. J Pharmacol Exp Therap 2002, 300:273-281.

6. Sikka SC, Rajasekaran M, Hellstrom WJ: Role of oxidative stress and antioxidants in male infertility. J Androl 1995, 16(6):464-468.

7. Ogeturk M, Kus I, Colakoglu N, Zararsiz I, Ilhan N, Sarsilmaz M: Caffeic induced nephrotoxicity and protective effect of betaine in Sprague Dawley rats. Urology 2005, 62:353-356.

8. Jia $X_{1}$ Han $C_{1}$ Chen J: Effect of tea on preneoplastic lesions and cell cycle regulators in rat liver. Cancer Epidemiology Biomarkers and Prevention 2002, 11:1663-1667.

9. Khan MR, Rizvi W, Khan GN, Khan RA, Shaheen S: Carbon tetrachloride induced nephrotoxicity in rat: Protective role of Digera muricata. J Ethnopharmacol 2009, 122:91-99.

10. Guo C, Lu Y, Hsu GSW: The influence of aluminum exposure on male reproduction and offspring in mice. Environ Toxicol Pharmacol 2005, 20:135-141.

11. Horn MM, Ramos AR, Winkelmann L, Matte US, Goldani HA, Silveira TR Seminiferous epithelium of rats with food restriction and carbon tetrachloride-induced cirrhosis. Intl Brazilian J Urol 2006, 32(1):94-99.

12. Parikh J, Chanda S: Screening of aqueous and alcoholic extracts of some Indian medicinal plants for antibacterial activity. Indian J Pharm Sci 2006, 68:835-838.

13. Khan RA, Khan MR, Sahreen S: Evaluation of Launaea procumbens use in renal disorders: A rat model. J Ethnopharmacol 2010, 128:452-461.

14. Ahmad M, Khan MA, Manzoor S, Zafar M, Sultana S: Check list of medicinal flora of Tehsil Isakhel, District Mianwali Pakistan. Ethnobot Leaflets 2006, 10:41-48.

15. Qureshi R, Bhatti GR: Ethnobotany of plants used by the Thari people of Nara Desert, Pakistan. Fitoterapia 2008, 79:468-473.

16. Shaukat SS, Siddiqui IA, Nasim Al: Nematocidal, allelophatic and antifugal potential of Launaea procumbens. Pakistan J Plant Pathol 2003, 2:181-193.

17. Lowry OH, Rosenberg NJ, Farr AL, Randall RJ: Protein measurement with of superoxide dismutase. Indian J Biochem Biophys 1951, 21:130-132. 
18. Chance B, Maehly AC: Assay of catalase and peroxidases. Methods Enzymol 1955, 11:764-775.

19. Kakkar P, Das B, Viswanathan PN: A modified spectrophotometric assay Folin Phenol reagent. J Biol Chem 1984, 193:265-275.

20. Iqbal M, Sharma SD, Zadeh HR, Hasan N, Abdulla M, Athar M: Glutathione metabolizing enzymes and oxidative stress in ferric nitrilotriacetate (Fe-NTA) mediated hepatic injury. Redox Report 1996, 2:385-391.

21. Habig WH, Pabst MJ, Jakoby WB: Glutathione-S-transferases: the first enzymatic step in mercapturic acid formation. J Biol Chem 1974, 249:7130-7139.

22. Carlberg I, Mannervik EB: Glutathione level in rat brain. J Bio./ Chem 1975 250:4475-4480.

23. Mohandas J, Marshal JJ, Duggin GG, Horvath JS, Tiller DJ: Differential distribution of glutathione and glutathione-related enzymes in rabbit kidney. Possible implications in analgesic nephropathy. Biochem Pharmacol 1984, 33:1801-1807.

24. Jollow DJ, Mitchell JR, Zampaglione N, Gillete JR: Bromobenzene induced liver necrosis. Protective role of glutathione and evidence for 3,4bromobenzene oxide as a hepatotoxic metabolite. Pharmacology 1974, 11:151-169.

25. Wu B, Ootani A, Iwakiri R, Sakata Y, Fujise T, Amemori S, Yokoyama F, Tsunada S, Fujimoto K: T cell deficiency leads to liver carcinogenesis in Azoxymethane-treated rats. Exp Biol Med 2005, 231:91-98.

26. Gilbert MT, Haselkorn T, Bunce M, Sanchez JJ, Lucas SB, Jewell LD, Van Marck $E$, Worobey M: The isolation of nucleic acids from fixed, paraffin embedded tissues, which methods are useful when? PLoS One 2007, 20(6):537.

27. Weber LW, Boll M, Stampfl A: Hepatotoxicity and mechanism of action of haloalkanes: carbon tetrachloride as a toxicological model. Crit Rev Toxicol 2003, 33:105-136.

28. Szymonik-Lesiuk S, Czechowska G, Stryjecka-Zimmer M, Słomka M, Madro A, Celin'ski K, Wielosz M: Catalase, superoxide dismutase, and glutathione peroxidase activities in various rat tissues after carbon tetrachloride intoxication. J Hepato-Biliary-Pancreatic Surg. 2003, 10:309-315.

29. Turner TT, Lysiak JL: Oxidative stress: A common factor in testicular dysfunctions. J Androl 2008, 29:488-498.

30. Yousef MI, Salama AF: Propolis protection from reproductive toxicity caused by aluminium chloride in male rats. Food Chem Toxicol 2009. 47:1168-1175.

31. Akunna GG, Ogunmodede OS, Saalu CL, Ogunlade B, Bello AJ, Salawu EO: Ameliorative Effect of Moringa oleifera (drumstick) Leaf Extracts on Chromium-Induced Testicular Toxicity in Rat Testes. World J Life Sci Med Res 2012, 2:20.

32. Akinsola AR, Adewale A, Oluwaseun H, Olusegun S, Adesina M: Effect of the methanolic extarct of Trichosanthes cucumerina seed (snake gourd/ tomatoe) on hormone influenced testes weight of adult Wistar rats. Webmed Central ANATOMY 2012, 3(6):WMC003498.

33. Mahmoud Yl: Effect of extract of Hibiscus on the ultrastructure of the testis in adult mice. Acta Histochem 2012, 114(4):342-348.

34. Hala AH, Khattab ZA, Abdallah G, Kamel M: Grape seed extract alleviate reproductive toxicity caused by aluminium chloride in male rats. J Am Sci 2010, 6(12):352-361.

35. Yousef MI, El-Morsy AMA, Hassan MS: Aluminium induced deterioration in reproductive performance and seminal plasma biochemistry of male rabbits: protective role of ascorbic acid. Toxicology 2005, 215:97-107.

36. Khan MR, Ahmed D: Protective effects of Digera muricata (L.) Mart. on testis against oxidative stress of carbon tetrachloride in rat. Food Chem Toxicol 2009, 47:1393-1399.

37. Ozturk F, Ucar M, Ozturk IC, Vardi N, Batcioglu K: Carbon tetrachloride acid phenyl ester protects kidney against carbon tetrachloride toxicity in rats. J Ethnopharmacol 2003, 97:273-280.

38. Khanna KK, Jackson SP: DNA double-strand breaks: signaling, repair and the cancer connection. Nat Genet 2001, 27:247-254.

39. Poirier H, Niot I, Clement L, Guerre-Millo M, Besnard P: Development of onjugated linoleic acid (CLA)-mediated lipoatrophic syndrome in the mouse. Biochimie 2005, 87(1):73-79.

40. Atessahin A, Yilmaz S, Karahan I, Pirincei I, Tasdemir B: The effects of vitamin $\mathrm{E}$ and selenium on cypermethrin-induced oxidative stress in rats. Turk J Vet Animal Sci 2005, 29:385-391.
41. Singh U, Jialal I: Oxidative stress and atherosclerosis. Pathophysiol 2006, 13:129-142.

42. Khan RA, Khan MR, Sahreen S: Protective effect of Sonchus asper extracts against experimentally induced lung injuries in rats. Toxicol. Pathol: A novel study. Exp; doi:10.1016/j.etp.2011.01.007.

doi:10.1186/1476-511X-11-103

Cite this article as: Khan: Protective effects of Launaea procumbens on rat testis damage by $\mathrm{CCl}_{4}$. Lipids in Health and Disease 2012 11:103.

\section{Submit your next manuscript to BioMed Central and take full advantage of:}

- Convenient online submission

- Thorough peer review

- No space constraints or color figure charges

- Immediate publication on acceptance

- Inclusion in PubMed, CAS, Scopus and Google Scholar

- Research which is freely available for redistribution

Submit your manuscript at www.biomedcentral.com/submit
C Biomed Central 